\title{
PENGARUH GANGGUAN BERBAHASA BERBICARA GAGAP DALAM KOMUNIKASI PADA WANITA USIA 16 TAHUN
}

\author{
Irma Khoirot Daulay ${ }^{1}$, Epiana Banjarnahor ${ }^{2}$, Thio Tarigan ${ }^{3}$ \\ Program Studi Magister Pendidikan Bahasa Indonesia \\ Universitas Prima Indonesia \\ Corresponding Author: irmaemhum@gmail.com
}

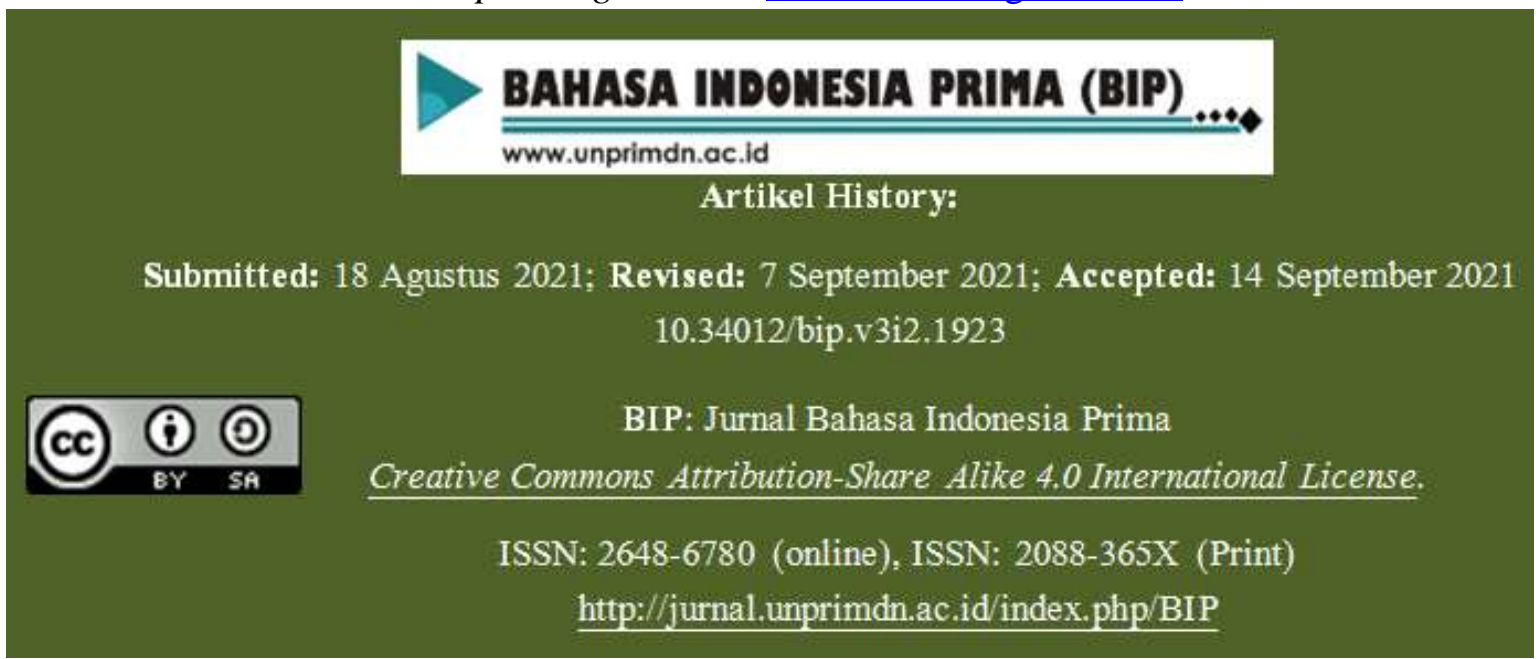

Abstrak-Ditinjau dari perkembangan bahasa, bahasa tidak lepas dari perkembangan bahasa lainnya. Perkembangan bahasa pada anak mempunyai beberapa tahapan hingga anak mampu berbahasa dengan baik. Beberapa dari tahapan tersebut, yaitu (1) perkembangan prelinguistik, (2) perkembangan fonologis, (3) perkembangan semantik, (4) perkembangan gramatikal dan (5) perkembangan pragmatik. Penyebab adanya kesulitan dalam berkomunikasi disebut dengan gangguan berbahasa.Gangguan berbahasa dapat disebabkan oleh terjadinya pada anak yang berkebutuhan khusus cenderung mempunyai gangguan maupun hambatan dalam berbahasa. Ganguan ini terjadi bisa secara langsung maupun secara tidak langsung.Gangguan yang terjadi secara tidak langsung misalnya kerusakan pada organ wicara, dan gangguan yang terjadi secara tidak langsung misalnya keterbatasan kognitif sehingga anak kesulitan dalam memahami makna dari suatu kata.

Kata kunci: gangguan berbahasa, berbicara, berpikir, dan gugup

Abstract-Judging from the development of language, language can not be separated from the development of other languages. Language development in children has several stages until the child is able to speak well. These stages are (1) prelinguistic development, (2) phonological development, (3) semantic development, (4) grammatical development, and (5) pragmatic development. The cause of difficulty in communicating is called a language disorder. Disturbances can be caused by the occurrence of children with special needs tend to have disorders or barriers in language. This disturbance occurs directly or indirectly. Disturbances that occur indirectly, for example, damage to the speech organ, and disorders that occur directly, such as cognitive limitations, so that children find it difficult to understand the meaning of a word.

Keywords: Language Disorders, Speaking, Thinking, and Nervous 


\section{A. Pendahuluan}

Pembelajaran bahasa berarti berkenaan dengan masalah berbahasa dan kegiatan berbahasa di dalam masyarakat. Kegiatan berbahasa berkaitan juga dengan proses atau kegiatan mental (otak). Psikolinguistik meliputi proses kognitif yang dapat menghasilkan kalimat yang mempunyai arti yang benar sesuai dengan tata bahasa perbendaharaan kata dan struktur tata bahasa. Sehingga ketika berkomunikasi, masyarakat yang menggunakan bahasa dapat memahami apa yang telah ungkapkan, sesuai dengan kata, tulisan, dan sebagainnya dengan benar. Hal tersebut berhubungan dengan fonologi karena setiap pemikiran akan diungkapan melalui bahasa dan bahasa tersebut berpengaruh kepada fonologi.

Proses berbahasa adalah proses berkomunikasi antara anggota masyarakat yang berupa simbol bunyi yang dihasilkan dari alat ucap manusia yang menggunakan bahasa tersebut. Sehingga berbahasa merupakan proses mengomunikasikan bahasa tersebut.

Proses berbahasa sendiri memerlukan pikiran dan perasaan yang dilakukan oleh otak manusia untuk menghasilkan kata-kata atau kalimat. Secara teoritis proses berbahasa dimulai dengan enkode semantik, enkode gramatika dan enkode fonologi. Enkode semantik dan enkode gramatika berlangsung dalam otak, sedangkan enkode fonologi dimulai dari otak dan diteruskan pelaksanaannya oleh alat-alat bicara yang melibatkan sistem syaraf otak bicara.

Ketiga enkode tersebut berkaitan dalam kegiatan produksi bahasa seseorang, yang juga berkaitan erat dengan hubungan antara otak dan organ bicara seseorang.

Manusia yang normal fungsi otak dan alat bicaranya tentu dapat berbahasa dengan baik. Namun, mereka yang memiliki kelainan fungsi otak dan alat bicaranya, tentu mempunyai kesulitan dalam berbahasa, baik produktif maupun reseptif (menerima tanggapan dari orang lain). Jadi, kemampuan berbahasa terganggu.

Salah satu bentuk dari kesalahan berbahasa adalah gangguan berbahasa gagap. Berbicara gagap berarti terdapat kelainan atau masalah kelancaran berbicara dalam pertuturan. Gangguan berbahasa gagap ini merupakan bagian dari kecacatan komunikasi yang menjadi suatu fenomena dalam kehidupan manusia. Gagap merupakan gangguan berbicara dengan indikasi tersendatnya pengucapan kata-kata atau rangkaian kalimat. Kelainan ini dapat berupa kehilangan ide untuk mengeluarkan kata-kata, pengulangan beberapa suku kata, kesulitan mengeluarkan bunyi pada huruf-huruf tertentu dan ketidakmampuan dalam mengeluarkan kata-kata sama sekali.

Pengaruh gangguan gagap dalam berkomunikasi ini menarik untuk dikaji dan diteliti, karena pengaruh gangguan gagap dalam berkomunikasi ini merupakan gangguan kelancaran berbicara yang dapat menghambat seseorang dalam berkomunikasi dengan orang lain, sehingga berpengaruh pada kondisi psikologis seseorang yang dapat berakibat fatal dan membuat seseorang terisolir dari lingkungan sosial dan pendidikannya.

\section{B. Hasil dan Pembahasan}

Menurut Sidharta (dalam Chaer, 2009: 148) gangguan berbahasa itu dapat di bedakan atas tiga golongan, yaitu gangguan berbicara, (2) gangguan berbahasa, dan (3) gangguan berpikir.

\section{a. Gangguan berbicara}

Menurut Chaer (2009: 149), berbicara merupakan aktivitas motorik yang mengandung modalitas psikis. Oleh karena itu, gangguan berbicara ini dapat dikelompokkan kedalam dua kategori. Pertama, gangguan mekanisme berbicara yang yang berimplikasi 
pada gangguan organik. Dan kedua, gangguan berbicara psikogenik.

\section{1) Gangguan Mekanisme Berbicara}

Menurut Chaer (2009: 149), Mekanisme berbicara adalah suatu proses produksi ucapan (perkataan) oleh kegiatan terpadu dari pita suara, lidah, otot-otot yang membentuk rongga mulut serta kerongkongan, dan peru-paru.

Gangguan berbicara berdasarkan meknismenya ini dapat dirinci menjadi gangguan berbicara akibat kelainan pada paru-paru (pulmonal), pada pita suara (laringan), pada lidah (lingual), dan pada rongga mulut dan kerongkongan (resonantal).

(a) Gangguan akibat Faktor Pulmonal

Gangguan berbicara ini dialami oleh para penderita penyakit paru-paru. Para penderitapenyakit paru-paru ini kekuatan bernafasnya sangat kurang, sehingga cara berbicaranya diwarnai oleh nada yang monoton, volume suara kecil sekali, dan terputus-putus, meskipun dari segi semantik dan sintaksis tidak ada masalah.

(b) Gangguan akibat Faktor Laringan

Gangguan pada pita suara menyebabkan suara yang dihasilkan menjadi serak atau hilang sama sekali. Gangguan berbicara akibat faktor laringan ini ditandai oleh suara yang serak atau hilang, tanpa kelainan semantik dan sintaksisnyaa. Artinya, dilihat darisegi semantik dan sintaksis ucapannya bisa diterima.

\section{(c) Gangguan akibat Faktor Lingual}

Lidah yang sariawan atau terluka akan terasa pedih kalau digerakkan. Untuk mencegah timbulnya rasa pedih ini ketika berbicara maka gerak aktivitas lidah itu dikurangi secara semaunya. Dalam keadaan seperti ini maka pengucapan sejumlah fonem menjadi tidak sempurna, sehingga misalnya, kalimat "sudah barang tentu dia akan menyangkal" mungkin akan diucapkan menjadi "hu ah ba- ang ke-ku ia a-an me- angkay”. Pada orang yang terkena stroke dan badannya lumpuh sebelah, maka lidahnya pun lumpuh sebelah. Oleh karena itu, cara berbicaranya juga akan terganggu, yaitu menjadi pelo atau cadel. Istilah medisnya disatria (yang berarti terganggunya artikulasi).

\section{(d) Gangguan akibat Faktor}

\section{Resonansi}

Gangguan akibat faktor resonansi ini menyebabkan suara yang dihasilkan menjadi bersengau. Pada orang sumbing, misalnya. Suaranya menjadi tersengau (bindeng) karena rongga mulut dan rongga hidun yang digunakan untuk berkomunikasi melalui defek di langit-langit keras (palatum), sehingga resonansi yang seharusnya menjadi terganggu. Hal ini terjadi juga pada ornag yang mengalami kelumpuhan pada langit-langit lunak (velum). Rongga langit-langit ini tidak memberikan resonansi yang seharusnya, sehingga suaranya menjadi tersengau. Penderita penyakit miastenia gravis (gangguan yang menyebabkan otot menjadi lemah dan cepat lelah) sering dikenali secara langsung karena kesengauan ini.

\section{2) Gangguan Akibat Multi faktorial}

Akibat gangguan multi faktorial atau berbagai faktor bisa menyebabkan terjadinya berbagai gangguan berbagai gangguan berbicara.

\section{(a) Berbicara Serampangan}

Menurut Chaer (2009:150), Berbicara serampangan atau semberono adalah berbicara dengan cepat sekali, dengan artikulasi yang rusak, ditambah dengan "menelan" sejumlah suku kata, sehingga apa yang diucapkan sukar dipahami. Dalam kehidupan sehari-hari kasus ini memang jarang dijumpai; tetapi didalam praktek kedokteran sering ditemui. Umpamanya kalimat "kmarin pagi saya sudah beberapa kali kesini" diucapkan dengan cepat menjadi "kemary sdada berali ksni". Berbicara serampangan ini karena kerusakan di 
serebelum atau bisa juga terjadi sehabis terkena kelumpuhan ringan sebelah badan.

\section{(b) Berbicara Propulsif}

Gangguan berbicara propulsif biasanya terdapat pada para penderita penyakit parkoinson (kerusakan pada otak yang menyebabkan otot menjadi gemetar, kaku dan lemah). Para penderita penyakit ini biasanya bermasalah dalam melakukan gerakan-gerakan. Mereka sukar sekali untuk memulai suatu gerakan. Namun, bila sudah bergerak maka ia dapat terus menerus tanpa henti. Gerak yang laju terus itu disebut propulsi. Pada waktu berbicara ciri khas ini akan tampak pula. Arti kulasi sangat terganggu karena elastisitas otot lidah, otot wajah, dan pita suara, sebagian besar lenyap. Dalam pada itu volume suaranya kecil, iramanya datar (monoton). Suaranya mula-mula tersendat-sendat, kemudian terus menerus, dan akhirnya tersendat-semdat kembali. Oleh karena itu, cara berbicara seperti ini disebut propulsif.

\section{(c) Berbicara Mutis (Mutisme)}

Penderita gangguan mutisme ini tidak berbicara sama sekali. Sebagian besar dari mereka mungkin masih dapat dianggap membisu, yakni memang sengaja tidak mau bicara. Mutisme ini sebenarnya bukan hanya tidak dapat berkomunikasi secara verbal saja tetapi juga tidak dapat berkomunikasi secara visual maupun isyarat, seperti dengan gerak-gerik, dan sebagainya.

\section{3) Gangguan Psikogenik}

Gangguan berbicara disebabkan segi mental atau psikogenik. Gangguan ini bersifat lebih „ringan" karena itu lebih tepat disebut sebagai variasi cara berbicara yang normalsebagai ungkapan dari gangguan mental. Modalitas mentalini terungkap dari nada, intonasi, intensitas suara, lafal, dan diksi atau pilihan kata. Ujaran yang berirama lancar atau tersendat-sendat dapat juga mencerminkan sikap mental si pembicara.
Gangguan psikogenik ini antara lain sebagai berikut:

\section{a. Berbicara Manja}

Berbicara manja karena ada kesankeinginan untuk dimanja sebagaimana anak kecil yang membuat perubahan pada cara bicaranya. Fonem (s) dilafalkan (c) sehingga kalimat "sakit sekali susah sembuhnya" menjadi "cakit cekali cucah cembuhnya".Gejala seperti ini dapat diamati pada orang tua pikun atau jompo (biasanya wanita).

\section{b. Berbicara Kemayu}

Menurut Sidharta (dalam Chaer, 2009: 153) istilah kemayu mengacu pada perangai kewanitaan yang berlebihan yang dalam hal iniditunjukkan oleh seorang pria. Berbicara kemayu dicirikan oleh gerak bibir dan lidah yang menarik perhatian dan lafal yang dilakukan secara menonjol atau ekstra lemah gemulai dan memanjang. Meskipun berbicara jenis ini tidak langsung termasuk gangguan berbahasa, tetapi dapat dipandang sebagai sindrom fonologik yang mengungkapkan gangguan identitas kelamin.

\section{c. Berbicara Gagap}

Menurut Chaer (2009: 153), Gagap adalah berbicara yang kacau karena sering tersendat-sendat, mendadak berhenti, lalu mengulang-ulang suku kata pertama, katakata berikutnya, dan setelah berhasil mengucapkan kata-kata itu kalimat dapat diselesaikan. Seperti orang yang ingin mengatakan, "awas ada pohon tumbang", tetapi ia mengucapkannya secara terputus dan berulang-ulang sehingga menjadi serperti berikut,

"a"....a..awawwaass.a..aa..add..a...pp

...po.hhon....ttu..tum...mbang". Apa yang menyebabkan terjadinya gagap ini masih belum diketahui secara pasti, tetapi hal-hal berikut dianggap mempunyai peranan penting penyebab terjadinya gagap: (a) Faktor stres dalam kehidupan berkeluarga, (b) Pendidikan 
anak yang dilakukan secara keras dan ketat, dengan membentak-bentak; serta tidak mengizinkan anak berargumentasi dan membantah, (c) Adanya kerusakan pada belahan otak (hemisfer) yang dominan, dan (d) Faktor neurotikfamial.

\section{a. Berbicara latah}

Menurut Chaer (2009:154), Latah sering disamakan dengan ekolalla, yaitu perbuatan membeo, atau menirukan apa yang dikatakan orang lain; tetapi sebenarnya latah adalah suatu sindrom yang terdiri atas curah verbal repetitif yang bersifat jorok (koprolalla) dan gangguan lokomotorik yang dapat dipancing. Koprolalla pada latah ini berorientasi pada alat kelamin laki-laki. Yang sering dihinggapi penyakit latah ini adalah orang perempuan berumur 40 tahun ke atas. Awal mula timbulnya latahini, menurut mereka yang terserang latah, adalah ketika bermimpi melihat banyak sekali penis lelaki yang sebesar dan sepanjang belut. Latah ini punya korelasi dengan kepribadian histeris. Kelatahan ini merupakan "excuse" atau alasan untuk dapat berbicara dan bertingkah laku porno, yang pada hakikatnya berimplikasi invitasi seksual.

\section{b. Gangguan Berbahasa}

Menurut Chaer(2009: 154), Berbahasa berarti berkomunikasi dengan menggunaakan suatu bahasa. Untuk dapat berbahasa diperlukan kemampuan mengerluarkan katakata. Ini berarti, daerah broca dan wernicke harus berfungsi dengan baik. Kerusakan pada daerah tersebut dan sekitarnya menyebabkan terjadinya gangguan bahasa yang disebut afasia, dalam hal ini broce sendiri menamai afemia. afasia ini dibedakan atas afasia ekspresi atau afasia motorik, yang dulu dikenal sebagai afasia tipe Broca dan afasia reseptif atau afasia sensorik yang dulu dikenal sebagai afasiaWernicke.

\section{Afasia Motorik}

Kerusakan belahan otak yang dominan yang menyebabkan terjadinya afasia motorik. Ada tiga macam afasia motorik yaitu: (a) afasia motorikkortikal, (b) afasia morotik subkortikal, dan (c) afasia motorik transkortikal.

a) Afasia motoric Kortikal

Tempat menyimpan sandi-sandi perkataan adalah korteks daerah broca. Maka apabila gudang penyimpanan itu musnah, tidakakan ada lagi perkataan yang dapat dikeluarkan. Jadi afasia motoric adalah hilangnya kemampuan untuk mengutarakan isi pikiran dengan menggunakan perkataan. Penderitanya masih mengerti bahasa lisan dan tulisan, namun ekspresi verbal tidak bisa sama sekali.

\section{a. Afasia Motorik Subkortikal}

Sandi-sandi perkataan disimpan di lapisan permukaan (korteks) daerah broca, maka apabila kerusakan terjadi pada bagian bawahnya (subkortikal) semua perkataan masih tersimpan utuh di dalam gudang. Namun, perkataan itu tidak dapat dikeluarkan karena terputus, sehingga perintah untuk mengeluarkan perkataan masih dapat disampaikan ke gudang penyampaian perkataan itu (gudang broca) sehingga ekspresi verbal masih mungkin dengan pancingan jadi penderitanya tidak dapat mengeluarkan isi pikirannya dengan menggunakan perkataan, tetapi masih bisa berekspresi verbal dengan membeo.

\section{b. Afasia Motorik Transkortikal}

Afasia motoric transkortikal terjadi karena terganggunya hubungan langsung antara daerah broca dan wernice. Ini berarti, hubungan langsung antara pengertian dan ekspresi bahasa terganggu. Pada umumnya afasia motoric transkortikal ini merupakan lesikortikal yang merusak sebagian daerah broca. Jadi penderitanya dapat mengutarakan perkataan subtitusinya. Misalnya, untuk mengatakan pensil sebagai 
jawaban atas pertanyaan "Barang yang saya pegang ini namanya apa?'. Dia tidak mampu mengeluarkan perkataan itu. Namun, mampu untuk, mengeluarkan perkataan, "itu ,tu ,tu ,tu ,untuk menulis." Afasia ini disebut juga afasianominative.

\section{Afasia Sensorik}

Penyebab terjadinya afasia sensorik adalah akibat adanya kerusakan pada lesikortikal di daerah Wernic kepada hemisferium yang dominan. Daerah itu terletak di kawasan asosiatif anatara daerah visual, daerah sensonik, daerah motorik, dan daerah pendengaran. Kerusakan di daerah Wernicke ini menyebabkan bukan saja pengertian dari apa yang didengar (pengertian auditorik) terganggu, tetapi juga pengertian dari apa yang dilihat (pengertian visual) ikut terganggu. Jadi, penderita afasia sensorik ini kehilangan pengertian bahasa lisan dan bahasa tulis. Namun, dia masih memiliki curah verbal meskipun hal itu tidak dipahami oleh dirinya sendiri maupun oleh oranglain.

Curah verbalnya itu merupakan bahasa baru (neologisme) yang tidak dipahami oleh siapa pun. Curah verbalnya itu sendiri dari kata-kata, ada yang mirip, ada yang tepat dengan perkataan bahasa apapun. Neologisme itu diucapkannya dengan irama, irama, nada, dan melodi yang sesuia dengan bahasa asing yang ada. Sikap mereka pun wajar-wajar saja, seakan-akan dia berdialog dalam bahasa yang saling dimengerti. Dia bersikap biasa, tidaktegang, marah, atau depresif. Sesungguhnya apa yang diucapkannya maupun apa yang didengarnya (bahasa verbal yang normal), keduanya sama sekali tidak dipahaminya.

\section{c. Gangguan Berpikir}

Menurut Chaer (2009:159) gangguan berpikir ada tiga hal yaitu: (1) pikun, (2) sisofrenik, dan (3) depresif).

\section{Pikun (Dimensia)}

Penyebab pikun terganggunya fungsi otak dalam jumlah besar termasuk menurunnya zatzat kimia dalam otak. Volume otak akan mengecil dan menyusut, sehingga ronnga dalam otak melebar. Pikun dapat disebabkan oleh penyakit seperti tumor otak, depresi, dan gangguan sistemik.

\section{Sisofrenik}

Menurut Chaer(2009:160) sisofrenik adalah gangguan berbahasa akibat gangguan berpikir. Seorang penderita sisofrenik dapat berbicara terus-menerus. Ocehannya hanya merupakan ulangan curah verbal semula dengan tambahan sedikit-sedikit atau dikurangi beberapa kalimat.

\section{Depresif}

Curah verbal yang depresi dicoraki oleh topik yang menyedihkan, manyalahi, mengutuk diri sendiri, kehilangan gairah berkerja dan gairah hidup dan tidak mampu menikmati kehidupan malah cenderung mengakhirinya.

\section{Gangguan Berbicara Gagap}

Pada bagian ini akan dijelaskan mengenai ganggun berbicara gagap yaitu(1) pengertian gangguan berbicara gagap, (2) gangguan berbicara gagap, dan (3) pengaruh gangguan berbahasa berbicara gagap dalam komunikasi.

\section{a. Pengertian Bicara Gagap}

Gagap atau stuttering merupakan salah satu bentuk kelainan bicara yang ditandai dengan tersendatnya pengucapan kata-kata. Gagap terjadi ketika sebagian kata terasa lenyap, penutur mengetahui kata itu, akan tetapi tidak dapat menghasilkannya (Cahyono, 1994: 262). Wujudnya secara umum, tiba-tiba anak kehilangan ide untuk mengucapkan apa yang ingin dia ungkapkan sehingga suara yang keluar terpatah-patah dan diulang-ulang seperti " $i$ i-ibu....", sampai tidak mampu mengeluarkan bunyi suara sedikit pun untuk beberapa lama. Reaksi ini bersamaan dengan kekejangan 
otot leher dan diafragma yang disebabkan oleh tidak sempurnanya koordinasi otot-otot bicara. Bila ketegangan sudah berlaku, akan meluncur serentetan kata-kata sampai ada kekejangan ototlagi.

Menurut Chaer (2009: 153), Gagap adalah berbicara yang kacau karena sering tersendat-sendat, mendadak berhenti, lalu mengulang-ulang sukukata pertama, kata-kata berikutnya, dan setelah berhasil mengucapkan kata-kata itu kalimat dapat diselesaikan.

Berdasarkan pendapat tersebut dapat disimpulkan bahwa, gagap berbicara merupakan gangguan bicara dan bahasa dimana aliran bicara normal (lancar) merupakan pengulangan sering terganggu oleh suara atau suku kata, perpanjangan kata-kata atau frasa dan penyumbatan aliran udara.

\section{b. Macam-Macam Gangguan Gagap}

Macam-macam gangguan gagap terdiri atas tiga hal yaitu: (1) gagap perkembangan, (2) gagap sementara, dan (3) gagap menetap.

\section{1) Gagap Perkembangan}

Gagap perkembangan biasa terjadi pada anak-anak usia 2-4 tahun dan remaja yang sedang memasuki masa pubertas. Kondisi gagap pada periode usia 2- 4 tahun merupakan keadaan yang masih wajar terjadi, karena hanya sebagai bagian dari proses perkembangan bicara anak. Gagap ini biasanya muncul disebabkan karena kontrol emosi penderita yang masih relative rendah,serta antusiasme seseorang untuk mengemukakan ide-idenya belum disertai dengan kematangan alat bicaranya.Sementara pada usia remaja biasanya disebabkan karena rasa kurang percaya diri dan kecemasan akibat perubahan fisik, mental dan sosial yang sedang dialaminya. Jadi, gagap padafase perkembangan merupakan gagap yang masih dalam tahap biasa dan wajar-wajar saja.

\section{2) Gagap Sementara/Gagap}

\section{Ringan}

Anak-anak usia 6-8 tahun sering mengalami gagap sementara,hal ini biasanya hanya berlangsung sebentar. Umumnya disebabkan oleh faktor psikologis, misalnya anak mulai memasuki lingkungan baru yang lebih luas, seperti lingkungan sekolah dan pergaulan, sehingga anak memerlukan waktu untuk menyesuaikan diri baik secara mental maupun sosial.

\section{3) Gagap Menetap}

Gagap ini dapat terjadi pada anak usia 38 tahun. Biasanya lebih banyak disebabkan oleh faktor kelainan fisiologis alat bicara dan akan terus berlangsung, sebagian kata yang akan dituturkan oleh penderita gagap akan terasa lenyap, meskipun penutur mengetahui akan kata-kata yang ingin dituturkannya, namun ia tidak mampu untuk menghasilkan kata-kata tersebut dengan sempurna. Anak yang menderita gagap menetap, alternatif penanganannya adalah dengan melakukan terapi wicara (speechtherapy).

\section{c. Faktor-Faktor Penyebab Gagap}

Gagap bisa disebabkan oleh faktor fisik maupun psikologis.Faktor fisik kemungkinan berasal dari keturunan yang menyebabkan ketidaksempurnaan secara fisik, seperti gangguan pada syaraf bicara, gangguan alat bicara, keterbatasan lidah. Sedangkan faktor psikologis yaitu ketegangan yang berasal dari reaksi seseorang terhadap lingkungannya, di antaranya adalah stress mental karena sesuatu yang dirasakan, namun tidak mampu untuk dilakukan. Menurut penelitian, gagap lebih banyak disebabkan oleh faktor psikologis disbanding fisiologis. Trauma, ketakutan, kecemasan, dan kesedihan pada masa kecil bisa menyebabkan seseorang menjadi gagap sampai dewasa. Misalnya, anak yang kedua orang tuanya sering bertengkar, sehingga 
membuat anak takut, cemas, sedih, dan sering menangis. Cara bicara yang gagap ketika menangis bisa menjadi kebiasaan sampai ia dewasa. Gagap bicara disebabkan banyak factor antara lain faktor biologis, sosiologis, dan psikologis.

\section{Pengaruh Gangguan Berbahasa Berbicara Gagap dalam Komunikasi}

Komunikasi merupakan suatu proses sosial yang sangat mendasar dan vital dalam kehidupan manusia. Dikatakan mendasar karena setiap masyarakat manusia, baik yang primitif maupun yang modern, berkeinginan mempertahankan suatu persetujuan mengenai berbagai aturan sosial melalui komunikasi. Dikatakan vital karena setiap individu memiliki kemampuan untuk berkomunikasi dengan individu-individu lainnya sehingga meningkatkan kesempatan individu itu untuk tetap hidup. (Dardjowidjojo: 2008).

Setiap saat semua orang selalu berbicara tentang komunikasi. Kata komunikasi sangat dikenal, tetapi banyak di antara kita yang kurang mengerti makna dari komunikasi walaupun kita selalu memperbincangannya dan melakukannya. Kata komunikasi atau communication dalam bahasa Inggris berasl dari bahasa Latin communis yang berarti "sama", communico, communicatio, atau communicare yang berarti "membuat sama" (to make common). Istilah pertama (communis) adalah istilah yang paling sering sebagai asal usul komunikasi, yang merupakan akar dari kata-kata Latin lainnya yang mirip. Komunikasi menyarankan bahwa suatu pikiran, suatu makna, atau suatu pesan dianut secara sama. (Wayne Pace dan Faules: 2006).

Komunikasi (communicare, latin) artinya berbicara atau menyampaikan pesan,informasi, pikiran, perasaan yang dilakukan seseorang kepada yang lain dengan mengharapkan jawaban, tanggapan, dari orang lain (Hohenberg : 1978). Komunikasi bermula dari sebuah gagasan yang ada pada diri seseorang yang diolah menjadi sebuah pesan dan disampaikan atau dikirimkan kepada orang lain dengan menggunakan media tertentu. Dari pesan yang disampaikan tersebut kemudian terdapat timbal balik berupa tanggapan atau jawaban dari orang yang menerima pesan tersebut. Dari proses terjadinya komunikasi itu, secara teknis pelaksanaan, komunikasi dapat dirumuskan sebagai kegiatan dimana seseorang menyampaikan pesan melalui media tertentu kepada orang lain dan sesudah menerima pesan serta memahami sejauh kemampuannya, penerima pesan menyampaikan tanggapan melalui media tertentu pula kepada orang yang menyampaikan pesan itukepadanya.

Komunikasi merupakan hal yang penting untuk kita berinteraksi dengan seseorang. Interaksi sosial akan menjadi baik jika seseorang dapat berkomunikasi dengan baik. Pentingnya sebuah komunikasi dalam melakukan hubungan dengan yang lainnya. Jika seseorang tidak bisa memahami apa yang kita bicarakan, orangpun akan sulit dan susah untuk mengerti apa yang kita bicarakan. Lalu bagaimana tetang seseorang yang mengalami gangguan bicara seperti gangguan gagap?, oleh karena itu alangkah baiknya jika kita mengetahui tentang gangguan gagap tersebut guna mencegah terhadap gangguan gagap tersebut.

Berdasarkan pendapat tersebut dapat disimpulkan bahwasanya adanya pengaruh gangguan berbahasa berbicara gagap di dalam komunikasi seseorang apalagi orang tersebut menderita gangguan berbahasa berbicara gagap orang akan sulit memahami apa yang kita bicarakan dan sulit untuk mengerti apa yang kita katakan. Adalah penelitian yang dimaksud untuk 
mengumpulkan informasi mengenai status suatu gejala yang ada, yaitu gejala menurut apa adanya pada saat penelitian dilakukan".

Arikunto (2007:236) menerangkan bahwa, "Metode survei merupakan satu jenis penelitian yang banyak dilakukan oleh penelitian dalam bidang sosiologi, bisnis, politik, pemerintahan dan pendidikan".Metode surveiini dimaksudkan untuk mengetahui, mengumpulkan pendapat atau informasi dari masyarakat mengenai status gejala pada waktu penelitian dilangsungkan. Berdasarkan dengan permasalahan penelitian dan pendapat ahli diatas, maka penelitian ini bertujuan untuk memberikan gambaran bagaimana pengaruh gangguan berbahasa berbicara gagap dalam komunikasi. Penelitian ini dilaksanakan pada hari Selasa, tanggal 9 Mei 2017 yang betempat di pasir parupuk Tabing, kecamatan Koto Tanggah, Padang.

Sugiyono (2009) menyatakan, "Variabel dapat didefenisikan sebagai atribut seseorang atau objek yang mempunyai variasi antara satu orang dengan yang lain atau satu objek dengan yang lain". Variabel dalam penelitian ini adalah variabel mandiri yaitu pengaruh gangguan berbahasa berbicara gagap dalam komunikasi.

Sample yang digunakan untuk objek dalam penelitian ini adalah seorang ibu rumah tangga yang berjualan kue yang berumur 46 tahun mengalami gangguan gagap.

Jenis data yang digunakan dalam penelitian ini adalah data primer. Data primer adalah data yang dikumpulkan atau didapat langsung dari responden dengan cara mewawancarai objek penelitian yang mengalami berbicara gagap. Teknik pengumpulan data yang digunakan adalah wawancara. Penelitian ini menggunakan seorang penyandang gagap sebagai sumber data yang menghasilkan data dan menjadi pembahasan dalam penelitian ini. Penelitian ini menggunakan bentuk wawancara langsung dengan sample yang diteliti. Kemudian hasil dari wawancara tersebut diolah menjadi sebuah data yang berbentuk penelitian dalam jenis desain deskriftif kualitatif, yaitu memaparkan atau menggambarkan hasil penelitian yang telah didapatkan peneliti sesuai dengan keadaan lapangan yang sebenarnya.

Analisis data merupakan langkah awal untuk menguraikan suatu pokok bagian dari suatu peristiwa, sehingga penelitian ini memberikan suatu makna terhadap data yang dikumpulkan. Tujuan menganalisis data apabila data belum memadai maka sebisa mungkin dapat segera dilengkapi sampai akhir penelitian.

Dalam penelitian ini menggunakan teknik analisis data model interaktif dari Miles dan Huberman dalam Sugiyono (2009:246), "Teknik analisis data kualitatif meliputi tiga alur kegiatan yakni: reduksidata, penyajian data, dan pengambilan keputusan".

\section{Reduksi data}

Menurut Sugiyono (2009:247), "Reduksi data adalah merangkum, memilih hal-hal pokok, memfokuskan pada hal-hal yang penting, dicari tema dan polanya”. Selanjutnya peneliti mengelompokkan data berdasarkan hal-hal yang akan diteliti yaitu pengaruh gangguan berbahasa berbicara gagap dalam berkomunikasi. Setelah data reduksi barulah data tersebut dianalisa dan dideskripsikan dalam uraian singkat yang mudah dimengerti dan dipahami.

\section{Penyajian data}

Setelah penelitian melakukan reduksi data, maka dilakukan penyajian data. Menurut Sugiyono (2009:249), "Penyajian data dilakukan dalam bentuk uraian singkat, bagan, hubungan antar kategori, flowchart 
dan sejenisnya”. Dengan menyajikan data maka akan memudahkan penelitian dalam pembahasan, untuk memahami apa yang sedang diteliti, serta dapat merencanakan kegiatan selanjutnya. Penyajian data identifikasi persepsi pengaruh gangguan berbahasa berbicara gagap dalam berkomunikasi dapat meliputi teks narasi, dan gambar dokumentasi dalam penelitian ini penulis menuangkan data yang direduksi.

\section{Pengambilan keputusan}

\section{Menurut Sugiyono (2009:252),} "Kesimpulan dalam penelitian kualitatif adalah merupakan temuan baru yang sebelumnya belum pernah ada. Temuan dapat berupa deskripsi atau gambaran suatu objek yang sebelumnya masih remang-remang atau gelap sehingga diteliti menjadi jelas". Dalam penelitian ini terlebih dahulu mengambil kesimpulan awal yang bersifat sementara tentang pengaruh gangguan berbahasa berbicara gagap dalam berkomunikasi. Setelah ditemukan buktibukti yang mendukung dan konsisten dilapangan dapat menjawab rumusan masalah yang dirumuskan, maka barulah dibuat kesimpulan yang sebenarnya sehingga hasil penelitian jelas maksud dan tujuannya barulah menerapkan suatu kesimpulan.

Penelitian ini menggunakan desain deskriptif kualitatif. Kealamiahan dari penelitian ini dapat dilihat dari objek yang digunakan, yaitu objek yang asli atau alamiah, tidak mengada-ada dan tentunya tidak ada manipulasi. Penelitian ini menggunakan seorang penyandang gagap sebagai sumber data yang menghasilkan data dan menjadi pembahasan dalam penelitian ini. Penelitian ini menggunakan bentuk wawancara langsung dengan sample yang diteliti. Kemudian hasil dari wawancara tersebut diolah menjadi sebuah data yang berbentuk penelitian dalam jenis desain deskriftif kualitatif, yaitu memaparkan atau menggambarkan hasil penelitian yang telah didapatkan peneliti sesuai dengan keadaan lapangan yang sebenarnya.

Dalam penelitian tersebut objek penelitian mengalami gangguan gagap Menetap. Gagap ini dapat terjadi pada anak usia3-8 tahun. Biasanya lebih banyak disebabkan oleh faktor kelainan fisiologis alat bicara dan akan terus berlangsung, sebagian kata yang akan dituturkan oleh penderita gagap akan terasa lenyap, meskipun penutur mengetahui akan kata-kata yang ingin dituturkannya, namun ia tidak mampu untuk menghasilkan kata-kata tersebut dengan sempurna. Anak yang menderita gagap menetap, alternatif penanganannya adalah dengan melakukan terapi wicara (speechtherapy).

Penelitian ini dilakukan pada seorang siswa (pelajar) yang berumur 13 tahun. Gejala ia mengalami gangguan gagap ini adalahia mengalami gangguan berbicara tersendak-sendak yang sangat berbeda dengan orang normal. Saat ia mengalami gangguan gagap ia mengatakan bahwa membutuhkan waktu sekitar 5- 7 detik untuk dapatbicara.Tiwi mengatakanketika ia mengalami gangguan gagap sementara atau gagap ringan ia mengalami kesulitan lambat dalam berbicara, dan biasanya disetiap awal dan pertengahan suku kata ia merasa kesulitan dan jika diibaratkan ketika ia berbicara ia merasa ada sesuatu yang tersendak didalam tenggorakan ataupun lidahnya sehingga mengganggu berbicaranya seseorangyang pengindap gangguan gagap ini, hingga sulit dan memperlambat untuk merespon apa yang ingin dikatakanya.

Berdasarkan penelitian di lapangan tepatnya di pasir parupuk Tabing, kota Padang. Pada hari selasa tanggal 10 Juli 2021. Observasi yang dilakukan dari kasus ini memang mempunyai masalah kegagapan. Tiwi sering mengulang- ulang kata dan kesulitan mengucapkan huruf-huruf 
tertentu ketika berbicara. Dia mengalami salah satu gangguan berbicara yaitu gagap bicara.

Menurut tetangganya, Tiwi menderita gagap bicara sejak Dia kecil, anak seusianya telah lancar berbicara tetapi Dia tidak seperti anak lainnya, kata yang diucapkannya diulangulang dan tidak lancar. Belum pernah mendapatkan bantuan baik medis maupun psikologis dari gangguan berbahasa gagap bicara yang dideritanya. Tiwi dan juga termasuk kepada orang tuanya yang mengalami gagap menetap, gagap yang tidak ada upaya atau ikhtiar disembuhkan seumur hidup. Biasanya lebih banyak disebabkan oleh faktor kelainan fisiologis alat bicara dan akan terus berlangsung, kecuali dibantu dengan terapi wicara (speech therapy).

Di pandang dari faktor penyebab gagap bicara yaitu pada faktor fisiologis yang berkaitan dengan masalah genetik, orang tua dari subjek observasi yang dilakukan memberikan keterangan bahwa ayah kandung dari si penderita juga mengalami gagap bicara yang juga dideritanya sejak kecil dan itu berlangsung sampai sekarang. Gagap bicara yang membuat Tiwi susah berkomunikasi dengan tetangganya karena orang terdekatnya memahami hal tersebut Tiwi sangat percaya diri dalam berkomunikasi dan sudah terbiasa berkomunikasi tersendat-sendat dan orang yang menjadi lawan tuturnya mengerti apa? yang dibicarakannya.

\section{Kesimpulan}

Berdasarkan hasil analisis data dan pembahasan pada BAB terdahulu, disimpulkan enam hal berikut. Pertama, Manusia yang normal fungsi otak dan alat bicaranya, tentu dapat berbahasa dengan baik. Namun, mereka yang memiliki kelainan fungsi otak dan alat bicaranya, tentu mempunyai kesulitan dalam berbahasa, baik produktif maupun reseptif. Jadi, kemampuan bahasanya terganggu.
Kedua, Gangguan berbahasa ini secara garis besar dapat dibagi dua. Pertama, gangguan akibat faktor medis; dan kedua, akibat faktor lingkungan sosial. Yang dimaksud dengan faktor medis adalah gangguan, baik akibat kelainan fungsi otak, maupun akibat kelainan alat-alat bicara. Sedangkan yang dimaksud dengan faktos sosial lingkungan adalah lingkungan kehidupan yang tidak alamiah manusia, seperti tersisih atau terisolasi kehidupan masyarakat manusia yang sewajarnya.

Ketiga, Secara medis menurutsidharta (1984) gangguan berbahasa itu dapat dibedakan atas tiga golongan, yaitu (1) gangguan berbicara, (2) gangguan berbahasa, (3) gangguan berpikir. Karena gangguan itu masih dapat diatasi kalau penderita itu mempunyai daya dengar yang normal; bila tidak tentu menjadi sukar atau sangat sukar.

Keempat, Berbicara merupakan aktivitas motorik yang mengandung modalitas psikis. Oleh karena itu, gangguan berbicara ini dapat dikelompokkan kedalam dua kategori. Pertama, gangguan mekanisme berbicara yang berimplikasi pada gangguan organik; dan kedua, gangguan berbicara psikogenik. Pada penelitian ini pengaruh gangguan berbahasa berbicara gagap dalam komunikasi.

Kelima, Gagap merupakan suatu gangguan bicara dimana aliran bicara terganggu tanpa disadari dengan adanya pengulangan dan pemanjangan suara, suku kata, kata atau frasa, sertajeda atau hambatan tak disadari yang mengakibatkan gagalnya produksi suara. Kalau dalam komunikasi, gagap merupakan salah satu gangguan irama kelancaran (disritmia) dalam tatananujaran.

Keenam, Hasil penelitian yang telah dilakukan, Ante Mar termasuk kepada orang yang mengalami gagap menetap, gagap yang tidak ada upaya atau ikhtiar disembuhkan seumur hidup. Biasanya lebih 
banyak disebabkan oleh faktor kelainan fisiologis alat bicara dan akan terus berlangsung, kecuali dibantu dengan terapi wicara (speech therapy). Faktor penyebab AnteMar menderita gagap bicara tergolong kepada faktor fisiologis yaitu berkaitan dengan masalah genetik atau gangguan organis. Sebab ayahnya juga mengalami gagap bicara.

Melalui penelitian ini sangat bermanfaat kepada: Pertama, kepada pembacaagar tidak memcemooh orang yang gagap bicara. Ketika kita berada diantara orang yang menderita penyakit gagap, sebaiknya kita menjadi teman atau sahabat baginya. Jika kita menjadi orang yang dekat bagi mereka, maka kita akan menjadi tahu apa yang sebenarnya mereka rasakan. Dengan demikian, orang yang menderita penyakit gagapakan menjadi orang yang merasa diperhatikan. Dengan itu mereka tidak akan merasa menjadi canggung untuk bercampur dengan masyarakat.

Kedua, Kepada yang mempunyai penyakit gagap, cobalah untuk lebih tenang dalam berbicara serta mencoba terapi yang bisa menghilangkan penyakit gagapnya tersebut.

Ketiga, disarankan kepada peneliti lain sebagai masukan dan perbandingan dalam melakukan penelitian yang berkaitan dengan masalah ini. Selain itu supaya dapat melakukan penelitian komprehensif, baik mengenai pengaruh gangguan berbahasa berbicara gagap dalam komunikasi maupun aspek-aspek lainnya.

\section{Daftar Pustaka}

Arikunto, Suharsimi. 2007. Manajemen Penelitian. Jakarta: Rineka Cipta. Cahyono, Bambang.

Yudi. 1995. Kristal-Kristal Ilmu Bahasa. Surabaya: Airlangga University.

Chaer, Abdul. 2009. Psikolinguistik: Kajian Teoritik. Jakarta; PT Rineka Cipta.

Dardjowidjojo, $\quad$ Soenjono. 2008. Psikolinguistik Pengantar Pemahaman Bahasa Manusia. Jakarta: Yayasan Obor Indonesia.

Hohenberg. 1978. Psycholinguistics: Language, Mind, and World. England: Longman.

Sugiyono. 2009. Metode Penelitian Kuantitatif, Kualitatif, dan $R \& D$. Bandung: Alfabeta. 